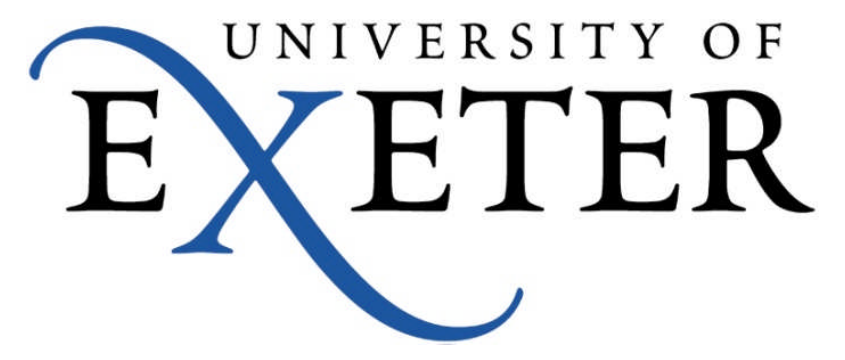

University of Exeter Institutional Repository, ORE

https://ore.exeter.ac.uk/repository/

Article version: Post-print

Citation: For final print version see Geoforum Volume 48, August 2013, Pages 268-278

Publisher website:

http://www.sciencedirect.com/science/article/pii/S0016718511000406

This version is made available online in accordance with publisher policies. To see the final version of this paper, please visit the publisher's website (a subscription may be required to access the full text).

Please note: Before reusing this item please check the rights under which it has been made available. Some items are restricted to non-commercial use. Please cite the published version where applicable. Further information about usage policies can be found at: http://as.exeter.ac.uk/library/resources/openaccess/ore/orepolicies/ 


\section{Writing biology with mutant mice: the monstrous potential of post genomic life}

Gail Davies, Department of Geography, University College London (gail.davies@ucl.ac.uk) Paper forthcoming in Geoforum, in a special issue on Monstrous Geographies, edited by Debra Dixon and Sue Ruddick

\section{Abstract}

Social scientific accounts identified in the biological grammars of early genomics a monstrous reductionism, 'an example of brute life, the minimalist essence of things' (Rabinow, 1996, p. 89). Concern about this reductionism focused particularly on its links to modernist notions of control; the possibility of calculating, predicting and intervening in the biological futures of individuals and populations. Yet, the trajectories of the post genomic sciences have not unfolded in this way, challenging scientists involved in the production and integration of complex biological data and the interpretative strategies of social scientists honed in critiquing this reductionism. The post genomic sciences are now proliferating points from which to understand relations in biology, between genes and environments, as well as between species and spaces, opening up future possibilities and different ways of thinking about life. This paper explores the emerging topologies and temporalities of one form of post genomic research, drawing upon ethnographic research on international efforts in functional genomics, which are using mutant mice to understand mammalian gene function. Using vocabularies on the monstrous from Derrida and Haraway, I suggest an alternative conceptualisation of monstrosity within biology, in which the ascendancy of mice in functional genomics acts as a constant supplement to the reductionist grammars of genomics. Rather than searching for the minimalist essence of things, this form of functional genomics has become an exercise in the production and organization of biological surplus and excess, which is experimental, corporeal and affective. The uncertain functioning of monsters in this contexts acts as a generative catalyst for scientists and social scientists, proliferating perspectives from which to listen to and engage with the mutating landscapes, forms of life, and languages of a post genomic biology.

\section{Keywords}

Monstrosity, excess, complexity, mutant mice, genetics, functional genomics 


\section{Writing biology with mutant mice: the monstrous potential of post genomic life}

\footnotetext{
'We need a critical hermeneutics of genetics as a constitutive part of scientific practices more urgently than we need better map resolution for genetic markers' (Haraway 1997, p160).
}

'There are now people working with genetically modified mice, who really are not animal researchers. The joke is they don't know which end bites' (Laboratory Animal Vet, interview 2009).

\section{On the margins}

Monsters are biotextual beings (Botting, 2003). They are of biology and text, material and semiotic, things and words, 'flesh and writing at the same time' (Milburn, 2003, p. 606). We most readily recognize them in their corporeal form; in the bodily destabilization of expected physiology or hybridization of separate species. This transformation of one kind of being to another is a monstrous event. Its arrival marks both the pathological and the normal body, for we only apprehend this addition to the normal through comparison with the illustrative texts of taxonomy, diagnostics or law (Canguilhem and Jaeger, 1962; Foucault, 2003). These texts produce the monster as much as the mutations, transpositions, substitutions and perversions that enable bodies to exceed their prior categorization. Monsters also reproduce in these textual circulations. The meanings of Frankenstein's monster proliferate, originating a genre of horror and re-articulating disgust and dread in considerations of contemporary biotechnology (Turney, 1998). Yet, Frankenstein it is also a story about responsibility and care. The meanings of the monstrous are not fixed. Back in biology, there are hopeful monsters too (Chouard, 2010). The monstrous birth can be a speciation event, a herald of new species to come (Milburn, 2003). These forms are initially unnameable, but come to take their place within the constant variation of the world. As Derrida remarks, 'the notion of the monster is rather difficult to deal with, to get a hold on, to stabilize' (Derrida, 1995, p. 385).

There is geography here as well as monsters take their place in complex ways. They are most commonly imagined as 'denizens of the borderland' (Milburn, 2003, p. 603), arriving from 
the boundaries of conventional knowledge, representing, at least initially, the limit to the order of things. If in the sixteenth and seventeenth centuries they inhabited the unmapped spaces beyond the known world (Daston and Park, 1998); and in the eighteenth and nineteenth they arose from the in-between states of natural history classifications (Ritvo, 1998); in the twentieth and twenty-first centuries, they seem to demonstrate a more explicitly political identity, fracturing the humanist assumptions of Enlightenment thought (Neocleous, 2005). Monsters increasingly appear in social theory too, not least within the 'French plague' of deconstruction (Freeman, 1987, p. 21), as Derrida returns repeatedly to the figure of the monster as a means of thinking otherwise. The monster is a deconstructive icon for exploring 'what may count as nature' (Haraway, 1992, p. 63), challenging totalizing conceptions of both nature and culture in contemporary biology. Monsters have valued theoretical affects; 'one must produce what in fact looks like a discursive monster so that the analysis will be a practical effect, so that people will be forced to become aware of the history of normality' (Derrida, 1995, p. 386). Yet, this aesthetic embrace of the monstrous raises questions about their enduring critical impact. The more we think we know where to find these strange material-semiotic actors, and what they embody, the more their transgressive qualities recede. The rapid reproduction of potentially monstrous bodies within artistic practices on the boundaries between art and biology, suggests that much contemporary bioart, in telling us what the monstrous looks like and placing it on the margins of mainstream biology may, despite probing critical commentary (Dixon, 2008), help keep it there. Derrida reminds us of these duplicitous qualities: 'as soon as one perceives a monster in a monster, one begins to domesticate it' (Derrida, 1995, p. 386).

This is a paper about encountering the monstrous in unexpected places and in unexpected forms, and the ethical necessity of both openness and hesitation as researchers seek to rewrite understandings of genetics through the production of mutant mice. It was prompted by the invitation to contribute to this special issue. I have written elsewhere about the potential for a geography of monsters (Davies, 2003), but this time I hesitated. It felt it might be a distraction; too much on the margins of current research tracing the circulation and regulation of genetically altered mice within contemporary functional genomics. The questions here are explicitly spatial: the co-ordination of large-scale mutant mouse resources, the translation of research from experimental sites to clinical practices, and the negotiation of multiple disciplinary and territorial boundaries; but, they are not immediately monstrous. The aesthetics in this sphere of biology are more perceptibly clinical than grotesque. The language of monstrosity would be plausibly resisted by my respondents, with their careful negotiation of animal welfare, ethical experimentation and medical expectation. Yet, there is 
something uncanny about this renewed grappling with animal forms within contexts marked out by the sequencing languages and coding practices of genomics. Perhaps monsters do not have to look monstrous to have disruptive or generative effects. This prompted a further hesitation, and so I agreed. The mundane laboratory mouse can perhaps be monstrous, if you don't know which end might bite.

The monstrous in this paper is thus a descriptive and interpretative concept. It draws attention to the gaps in sense-making, and the grasping towards new ways of understanding, as molecular biologists trained in the vocabularies of mathematics seek to understand gene function through the excessive corporeality of laboratory mice. The account makes use of the art, architecture, language, experimental apparatus and embodied animal forms encountered in ethnographic exchanges with these individuals and institutions ${ }^{1}$. These resources offer insight into the potential for meanings and materials to translate across lacunae, but they also indicate transgressions. The narrative that follows is thus not linear, but looping, returning repeatedly to the points of hesitation, as meanings fail to articulate and new possibilities and aporias emerge. From the work of Derrida, it takes the monster as a recurrent supplement, or outgrowth, of the biotextual forms and spatial logics used to understand early genomics, as work with these strange animal bodies alter its histories and its futures. From Haraway, this promise of monsters emerges from a 'mapping exercise', a travelogue around mindscapes and landscapes, which connect the material and semiotic, and resist an easy return to ethical calculation (Haraway 1992; 2008). Both also refuse a singular definition of the monstrous, indeed to do so would defeat the point: 'a monstrosity never presents itself' (Derrida, 1990, p.79). The article thus performs its own monstrosity, for these translations and transgressions are not settled; incoherence is part of the story. It narrates these breaches through the moments of hesitation, the pause within the ethnographic moment, the realizations that mice can bite. It asks you to read slowly, and consider how we open ourselves, through science, art, ethics, language and social scientific interpretation to an encounter with the unknown, the strange and the multiply monstrous potentialities of post genomic life.

\footnotetext{
${ }^{1}$ This paper draws on research completed as part of a set of projects around 'Biogeography and Transgenic Life', funded by an ESRC research fellowship, grant number RES-063-27-0093. It is based on ethnographic research and in-depth interviews exploring the use of mouse models in international functional genomics carried in Europe and the USA in 2009. The use of mice as models is only one of many appraochs to understanding gene function in what is sometimes characterised as the post genomic sciences. Systems biology, epigenetics, proteomics, and other model organism research would all be additional examples. The questions raised by the use of mice are slightly different, given the regulation of mammalian research and the broader cultural context to animnal experimentation. The research involved around 90 interviews with a diversity of research scientists, laboratory veterinarians, animal welfare scientists, funders and regulators, as well as participation in research meetings and international conferences. All research participants were offered anonymity.
} 


\section{Of mice and monsters}

Understanding this incipient monstrosity requires further reflection on the changing nature of what is ruled out of bounds, what is felt to be monstrous, in contemporary biological practice. What was monstrous in the Sixteenth or even Nineteenth century biology no longer holds the same repugnant fascination or destabilizing power. In the particular conjuncture of post genomics, as biologists seek to make biological sense of the abundance of molecular information generated by sequencing efforts, the relations between biology as text and biology as the thing itself are shifting again (Franklin, 2006). At its peak, the language of molecular biology was a reductionist one; a forcing of flesh into digital format. Yet even before the mapping of coding operations proclaimed as foundational to life were completed, a proliferation of alternative approaches for understanding biological relations were emerging, post genome, around proteomics, systems biology, epigenetics, gene-environment interactions, and so forth. As Sarah Franklin puts it, 'the silence of the genome has given way to the cacophony of the epigenetic' (2006, p. 169). This is not merely a shift in biological grammars, but of biological practices too. A generation of molecular biologists, whose educational trajectory was oriented to expect the future of biological enquiry to be completed in vitro and in silico, are returning in large numbers to study life in vivo. After a period scattered at the margins, the mouse is returning to the large-scale centres of contemporary biology as model organisms in functional genomics, as one part of these post genomic endeavours (see for example, Abbott 2004; Rosenthal and Brown, 2007; Gondo, 2008). Everything put aside to focus on the coding operations of the genome is returning, overwhelming biological grammars developed to articulate genomic sequences and the language of critical scholars of science honed in critiquing this reductionism. In the specific aftermath of functional genomics, the animal body itself carries the weight of a disruptive, but also hopeful, monstrosity.

It is not just in genomics that apparently ordinary animals have monstrous connotations. The parallel between modernist art and genomic biology may be instructive (Pickstone, 2001). In The Postmodern Animal, Steve Baker argues there is 'no "modernist" animal', that the 'animal is the very first thing to be ruled out of modernism's bounds' (Baker, 2000, p. 20; see also Ellman 2004, p. 61). In the aesthetic cultures of modernism, animals exemplify the 'human imagining-itself-other', primarily through dreams of mobility and transcendence. This is exemplified in the visions of Brancusi, whose fish and birds shed their animality, striving toward an ideal of unimpeded movement through water or air. The scales, feathers, pelt and weight of the animals fall away. The monstrous here is the corporeal; the body itself 
becomes excessive to these dreams of overcoming flesh. The correspondence with the elementariness and technological hubris of genetics are effective. So too, in this context, is the critical 'promise of monsters' in social scientific analysis, to disturb these visions through tracing profane, fleshy and hybrid collectivities (Haraway, 1992; Ruddick, 2004).

Yet, even without such critical assistance, animals resist this banishment. The animals that crawl back in, who refuse to be ruled out of modernism's bounds, are the mice, rats and other commensal animals that swarm within the interstices of modernist structures ${ }^{2}$. These animals challenge modernisms ideas of purity, of control, and of territory, reinhabiting both imaginative and material worlds. Writing about rats, Ellman suggests that, 'What bothers modernism about rats is their refusal to be kept in bounds, whether of number or locality; they multiply too fast, and spread too far. Literally gnawing through the walls of man-made structures, rats in modernism augur the collapse of boundaries, especially the boundaries of meaning' (2004, p. 62). Mice are similarly liminal creatures. They mature early and breed rapidly. Their teeth continually grow, allowing them to eat and access a range of food. Whilst rats are most reviled for their ability to feed on waste and each other, mice are renowned for being able to lay waste to food, destroying not only crops, but also the containers used to accumulate resources (Crowcroft, 1966). For both, their apparently excessive appetite for food and sex means they are a threat to both food security and moral standards. These rodents 'imitate the human's own prodigious appetite. They are like an anti-system, the embodiment of a drive to consume and nothing more' (Burt, 2006, p. 46). Their monstrosity emerges from their apparently limitless potential for reproduction and consumption; for their unchecked excess.

Rats and mice refuse to be kept in place. They are cosmopolitan, versatile and resilient, eating 'away the bounds of countries and cultural traditions with the rapacity of a multinational company' (Ellman, 2004, p. 62). Rats and mice disturb modern ideals of circulation and globalization, following trade routes, bringing disease and disruption, inhabiting transport networks, scurrying through the sewers and other mazes of modernity. Mice have travelled to all parts of the globe occupied by humans, following waves of human migration, and enjoying population explosions around settled forms of farming and calorific urban environments (Boursot et al, 1993). They are a diverse and adaptable species, able to live in all environments from the tropics to the tundra (Berry, 2008), from warm apartment blocks to cold meat stores. They live socially, in anything from small family groups to 
swarms of literally thousands of animals ${ }^{3}$. These monstrous forms erupt periodically, but are the product of the very systems they disturb.

There have been historic attempts to incorporate mice under the auspices of human authority and law. In these attempts, another characteristic of these rodent species is evident; their capacity to unbind reason by eating through language. In The criminal prosecution and capital punishment of animals, Evans (1906) details the place of animals in the ecclesiastical courts of early modern Europe. Judicial proceedings were regularly instituted against a variety of 'rats, mice, locusts, weevils and other vermin', expelling them from orchards, vineyards and cultivated fields by means of excommunication (Evans, 1906, p. 2). On one occasion, in the 1580s, these pests have been attacking vineyards in the south of France. An advocate is appointed for the animals and a visit to the vines arranged to survey the damage. The ecclesiastical court meets, but the sitting is constantly adjourned as arguments circle around the place of these animals within law and the potential for finding them land outside the vineyard. The book recounts these moral and spatial complexities for several pages. Yet, despite repeated sittings the outcome remains obscure. 'The final decision of the case, after such careful deliberation and so long delay is rendered doubtful by the unfortunate circumstance that the last page of the records has been destroyed by rats or bugs of some sort' (Evans, 1906, p. 49). Elsewhere, 'Rabelais complains that rats have eaten the beginning of his book; and Racine reminds his son to tell his mother to put a little water in the bookcase to prevent the mice from devouring his library' (Ellman, 2004, p. 70). The animal's surplus gnaws through language and the law used to try and tame them.

More recently, the biological exuberance of these animals has been more thoroughly, though not totally, domesticated. Karen Rader provides a compelling history of the process of making standardized laboratory mice from the late nineteenth century to the 1950s (Rader, 2004). It was from the Victorian fancy rat and mouse societies that early experiments in breeding developed the inbred strains critical to twentieth century developments in cancer research, toxicology testing and mammalian genetics. The very characteristics which made these animals pests, their resilience in the face of inbreeding and their fast reproduction, made

\footnotetext{
${ }^{2}$ As Elizabeth Costello reflects in Coetzee's novel of the same name: 'Rats haven't surrendered. They fight back. They form themselves into underground units in our sewers. They aren't winning, but they aren't losing either' (2003, p. 105).

${ }^{3}$ The destructive capacities of mouse swarms are more commonly associated with the corn ricks and storage barns of pre-industrial agriculture, but they can still be seen in footage filmed in Southern Australia in 1993. Search for mouse swarm or plague on the internet, and the video that most often comes up is a recording, screened on the Guinness world record show, showing mice swarming within the livestock sheds of Australian farms. The first frames of the footage warns you may find the images offensive; yet it is only mice. Just lots of mice, more than you might want to imagine.
} 
them easy to reproduce in large number and identical form in the laboratory. This domestication does not happen once, but repeatedly, with the identification of locally interesting animals and the divergent activities of individual laboratories. The result is a swarm of inbred mouse strains across the laboratories of the world; the mouse genealogy map identifying at least 450 different strains (Beck et al, 2000). Yet, following the period covered by Rader's book, mice become more marginal figures, at least within sociological narratives of post-war biological innovation. They figure as only bit parts in the main dramas of molecular biology and embryology, taking supporting roles as experimental precursors or assembled into experimental apparatus as merely feeder cells (Franklin, 2006). There is no social scientific analysis of the development of mouse embryonic stem cells; biopolitical commentaries move quickly from experiments in mouse IVF to something larger and more interesting. In tracing the phases of pharmaceutical development there is considerable attention to human clinical trials, but little on these animal's contributions to pre-clinical testing (Lezaun, 2010). Where they do feature, it is as emblematic of the contestation of intellectual property claims in the patenting of mammalian genes (Haraway, 1997; Robins, 2008). In these practices, genetics comes to the fore and the animal body is restrained in pursuit of the production and ownership of biological information.

It is after the mapping of the genome that the mouse body re-emerges as the duplicitous supplement to genetics. Akin to Derrida's monstrous arrivant, the mouse arrives again from the margins, functioning as a biological excess, decentring the logocentric assumptions in genetics, revealing their partial domestication to the grammars of biology in which they are inserted. Laboratory mice retain their ability to decompose 'connections, unweaving webs, untying texts, unnetting networks' (Ellman, 2004, p. 70). They may again be eating the words we use to try to tame them, rewriting the texts of biology and remaking the biotextual forms in which we meet the monstrous.

\section{Supplementing Genomics}

Figure 1 is an aerial view of a gene sequencing centre, which played a key role in the sequencing of the human genome from 1990 to 2003. A version of this photograph is reproduced in the entrance hall to this site, alongside an artistic representation of the array of letters which are the outcome of this mapping project. I set up a visit to explore what they are doing now. Once I have met my contact, and completed the introductory protocols of cordiality and security, we tour the facilities. As we set off, he pauses in front of this view. This, he says, reflects the change in emphasis in our work. 


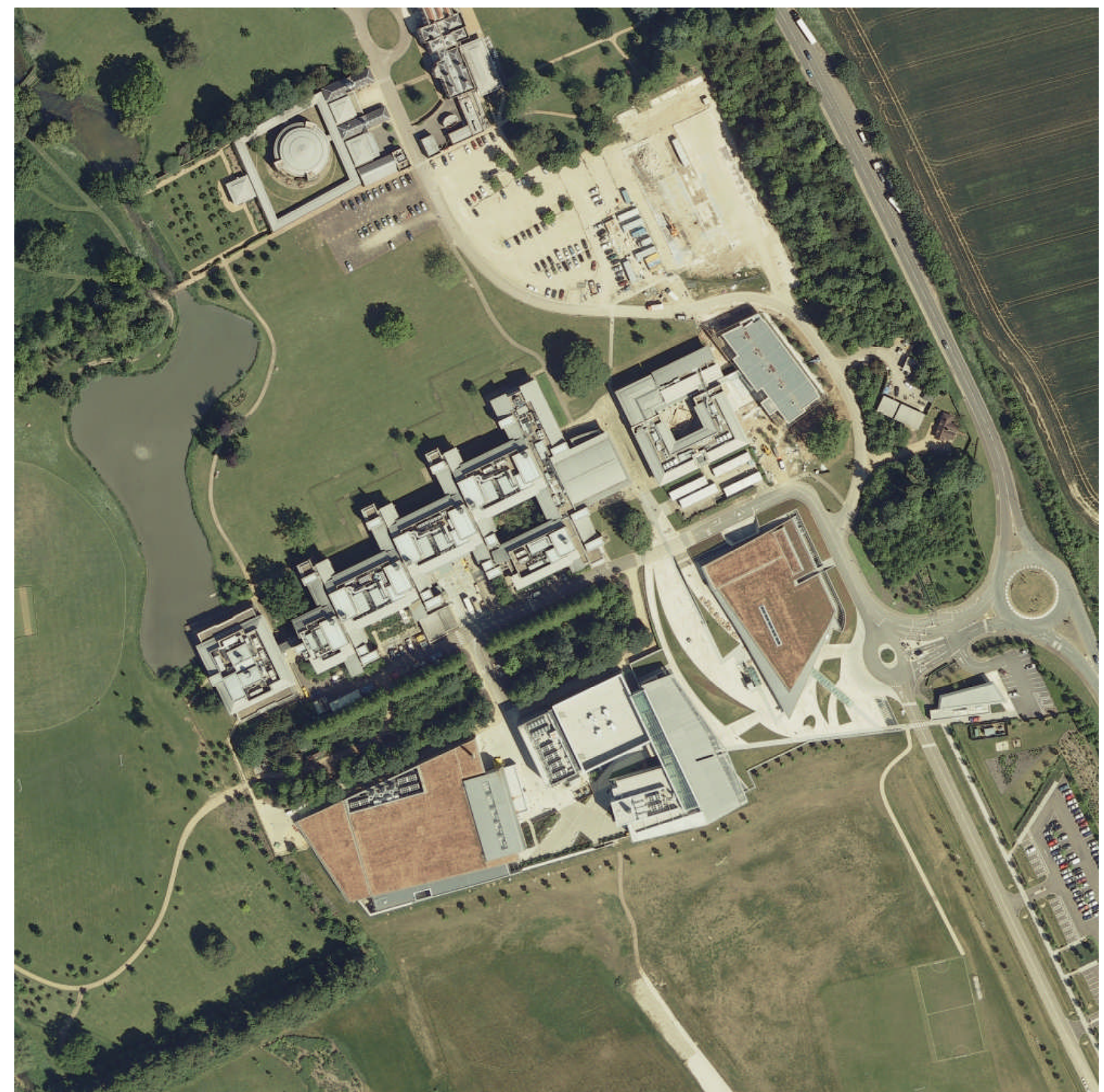

Figure 1: Aerial Photograph of Centre for Gene Sequencing and Functional Genomics

He points out the buildings to the north of the site, pictured at the top of the image. These are grey, box-like structures, arranged at a series of angles. They juxtapose awkwardly with the landscape. He makes the analogy that they look like a series of non-descript grey office computers, ones that were ubiquitous in the late 1990s. And they do, he says, contain a lot of computers. The buildings were the main site for the sequencing work done here to map the human genome. This was an internationally collaborative, and at times, competitive effort, with individual researchers working on mapping different chromosomes or genes (CookDeegan, 1994; Balmer, 1996). The majority of this work was achieved using biological samples and large sequencing computers. It is biology as code, genomics as technics; its relation to the rest of biology, to the landscape around it for the time being irrelevant. He tells me the buildings are organized into linear corridors, each focusing on a given area of the 
genome. These elements could then be easily added together. All had shared understandings of this project, mapping the complexity of biology to extract a four letter code.

The adjacent artwork is a representation of the outcome of this mapping project. It is a long list of letters - A T C G - placing the 3 billion base pairs that make up human DNA. The project was completed early and with considerable publicity, which at the time portrayed it as the ultimate description of humanity. The logocentrism at the centre of genomics has been the subject of considerable commentary (Rabinow, 1996; Kay, 2000; Botting, 2003). This critique is enmeshed with a particular notion of genetic essentialism that positioned the gene as originary code for the creation event of each species and for each individual of that species. However, the eventual story of the human genome project was not about what the genome 'told us': it was, and has been increasingly since, about what the genome didn't reveal (Keller, 2002; Clayton, 2005). On its own, this long list of letters tells us very little. Without establishing relations - between species and between genes, proteins, pathways and bodies it is a map without a referent, the ultimate reduction of human biology to mere DNA.

He then points out the newer set of buildings to the south. These are rounded, placed within the landscape, planted with sedum roofs and fronted with cedar wood, which has weathered to a warm brownish cream. They are, he says, fuzzy organic structures. This is the location of research to add the complexities of biology back onto this genetic sequence. It is here they are developing their work in functional genomics, searching for the functions and interactions of each mapped gene in whole organisms. They do this by working with model organisms; by developing an array of mouse embryonic stem cells, then deriving mice which have a known genetic alteration. These can then be phenotyped, their bodies and behaviours examined to look for the resulting structural, metabolic, sensory, cognitive and affective changes, which provide clues to gene function and, the hope is, new ways of understanding and intervening in the trajectories of human disease. The building to the bottom left is central to this initiative; it is the new mouse house, where the animals are kept, genetic alterations produced and mutant mice archived.

Two other structures accompany this facility. To the right, another green roofed building with café, meeting rooms, lecture halls, a library and public engagement centre, encourages communication between sub-disciplines, which now need to work together. Rearticulating biological complexity with genomics is not only about producing new animal models; it is also about the challenging task of integrating sequencing technologies, mouse genetics, animal pathology, behavioural ethology, and clinical practice. These exceed the settlements of biological nomenclature, technological form and funding structure that characterized the 
human genome project. Functional genomics requires additional translations between different species, practices and languages, and across different spaces too. These interactions take place informally, in conferences, and on-line. In the centre, towards the bottom of the image, is a building more closely resembling those above. This is the new bioinformatics building, with the computational power to process this new information. Whereas the first set of buildings was about constructing biological data through computers and as code, this second set of buildings is designed to generate biological data through the practices of mutation; though the generation of monsters perhaps. Yet, technical diagramming is still crucial to efforts to make sense of the potential of this biological excess (Leonelli, 2008). This is after all big science, and the data generated here have to coordinate with other international initiatives, even if these are now more complex to standardize and integrate.

Like the human genome project, the diverse practices of functional genomics are advancing on an international stage. The complexity of post genomics means there are more sites and practices involved in creating, characterizing, distributing and archiving mutant mice. There are Mutant Mouse Regional Resource Centres across the North America, there are the networks of the European Mouse Mutant Archive, the Knock Out Mouse Project or KOMP spans these continents, there are consortia developing mouse models for specific disease areas, and there are further centres for research in Australia, Japan and China (see Davisson, 2006). These facilities are using different methods to produce genetically-altered animals: knocking out genes, developing conditional mutants and transgenic animals, mutating genes using chemical mutagens, and developing new genetic forms through a collaborative cross of older inbred strains. Not all centres currently collaborate, but many face similar challenges from this sudden invasion of mice. There is the reorganization of the spaces of molecular biology to accommodate animals, the rising costs of mouse houses, the additional ethical scrutiny around animal experimentation, the difficulty of standardizing phenotyping and collating data across different institutions, and the challenge of prioritizing the new uncertainties and new opportunities amassed through this research (Collins et al, 2007). At this centre, they are knocking out genes out to see what happens (Austin et al, 2004). They are, I am told, the largest producer of mouse knockouts on the planet. Many of these mutations currently exist only as mouse embryonic stem cells. Fewer have been fully characterized for their value as mouse models of human diseases. Though there are plans to do so, this remains a complex, challenging and still contested part of the endeavours of functional genomics.

At this stage it is possible to say this programme of post genomic research is monstrous in at least three senses of the word. It is monstrous in its scale. This scaling up from biology as code is not merely additive, but involves the creation and articulation of new interdisciplinary 
spaces, whose patterns are still evolving. The challenge of synthesizing the outcomes of research from the diverse sites and forms of experimentation in functional genomics destabilizes some aspects of genetics through which it was initially conceived. Assumptions about the predominance of linear and repeatable links between DNA code, protein, pathway, and phenotype, that the same cause will produce the same effect, always and everywhere, are permanently perturbed. The work of functional genomics is a supplement to the work of mapping gene sequences; yet, the supplement not only adds to, but also offers an unceasing preface to what it means to define a gene and effect. 'The supplement supplements. It adds only to replace. It intervenes or insinuates itself in-the-place-of' (Derrida, 1998, p. 145).

This shift in the grammars of biology introduces other monstrous qualities, of biology and text, and biology as text. It is secondly potentially monstrous in its repositioning of the differentiated body at the centre of biology. In the place of biology as code, this is biology as mutation. Rather than searching for the normal, the ideal type, or the singular genetic code from which variations are defined, here difference is of central interest and value. And thirdly, it is monstrous in the sense that it is oriented to the production of a variety of possibilities, not all of which will become facts. It is open to the future - to the monstrous arrivant - in a way that the sequencing practices of human genome project were not - though as I will suggest it is not always able to welcome these monsters.

\section{Generating mutants}

In the second encounter, I am in the mouse house. Here mutant mice are being produced using an alternative method called mutagenesis. Whereas knockout mice have a known gene altered, N-ethyl-N-nitrosourea (ENU) mutagenesis uses a powerful chemical mutagen to produce unknown mutations in the mouse genome. The animal's offspring can then be phenotyped to trace the bodily effects of altered gene expression, which may be useful in understanding mammalian development and identifying new animal models for human diseases. This research also takes place within a recently constructed animal house. I am given a tour of the site, which requires us to don protective clothing and air shower before entering a sterile barrier facility. Inside, we pause before what might be considered a conveyor belt for generating mutants, as my guide explains this process to me.

In front of us is a rack of shoe-box sized clear plastic cages. They are stacked about 12 high and 6 along. They are connected to an air filtration system, provisioned with food pellets and a water bottle, and furnished with sawdust and a cardboard tube. Each cage contains three 
animals: two females and one male. The males have been injected with ethyl-nitrosourea or ENU. ENU produces germ line mutations. This is the start of the experiment. The future generations are examined for the outcomes of any gene misexpression. Dominant mutations may be picked up in the first litter of pups, but identifying recessive mutations may take further generations (Hrabé de Angelis et al, 2000). Additional litters may be needed to determine whether the mutation is inherited, crosses can be necessary to locate the identity of the altered gene and breeding may be required to shift the mutation onto a stable inbred strain background, turning the mutant animal into a useable scientific tool. At this stage though, the specific effect of this mutagen on these animals is unknown. The technique was developed for large-scale screening of mutants in drosophila flies, though it also has echoes of post-war research on the mutagenic effects of radioactivity. It has only recently been adopted for largescale genetic screens in mammals, and for some it is controversial (Qiu, 2006). To others, it is the best way of producing mutants with novel potential for developing understandings of human biology (Balling et al, 2000). Whereas other forms of genetic alteration start from what is already known, to target specific genes, this strategy generates surprises. ENU makes no assumptions about the gene, or the molecular pathways, involved in producing bodily difference. It is potentially open to all possibilities which might offer new models and understandings of human disease. The mathematical precision and prediction, the species code, apparently promised at the initial stages of the human genome project seem a long way away. This experiment is open to the future, to biological emergence beyond our current understanding, to the monstrous arrivant.

If the representational practices of both art and science are considered useful to understanding the modernist syntax of the human genomic project (Anker and Nelkin, 2004; Schlick, 2005), an alternative perspective may be beneficial here. The comparison can be made between approaches to knowledge personified by two British men, both named Francis Bacon, divided by centuries and by scientific and artistic focus. The first, the scientist philosopher, put mathematics at the centre of his quest for knowledge at the start of the Enlightenment. In the 'Advancement of Learning' (1605), he writes against objections to empirical investigation, advocating knowledge as central to human advancement, separating man from animality and ultimately transcending corporeality. 'By learning man excelleth in that wherein man excelleth beasts; that by learning man ascendeth to the heavens and their motions, where in body he cannot come' (Bacon, 1994, p. 48). Later, in the same text, he suggests natural philosophers should learn from the language of mathematics, seeking 'in all controversies and disputations to imitate the wisdom of the mathematicians, in setting down in the very beginning the definitions of our words and terms' (Bacon, 1994, p. 99). His words prefigure the mathematical basis of scientific experimentation and the modernist preoccupation with 
overcoming animality and corporeality. The second, the twentieth century British artist Francis Bacon, also deals with the relationship between representation, corporeality and epistemology, returning to figuration after the height of abstraction in painting. In his account of Bacon's work, Deleuze suggests that to do so involved a new approach to perception and equivalence. 'Bacon's constant formula' Deleuze writes, 'was to create resemblance, but through accidental and non resembling means' (2005, p. 60). 'It is like the emergence of another world. For these marks, these traits, are irrational, involuntary, accidental, free, random. They are no longer either significant or signifiers: they are asignifying traits.' They introduce 'possibilities of fact' (p. 71).

The parallels with the return of the body to biology, after the hubristic grammars of the human genome project, are provocative. In this experimental formulation, biological understanding proceeds through the adventitious production of these multiple and multiply differentiated bodies. Yet, many of these animals lack the markers associated with classical notions of monstrosity. Gross developmental abnormalities are relatively rare; in fact, many animals generated by ENU appear surprisingly normal. ENU produces often subtle point mutations on a single gene. The idea of the monster is closely related to what is normal, but here it is the normal animals which are of little interest. The normal phenotype does not invite further enquiry, we can learn nothing new from them. In fact, the number of normal animals is a problem for this experimental system. Such normality is excessive to its demands for emergence. This approach is known as forward genetics: it is from the mutation event that the potential for future understandings of corporeal difference emerge. This differentiated body precedes the naming of the trait, or the identification of the gene. These random moments of biological emergence are freed from the assumptions of existing knowledges and forms. As in the return to figuration in painting, these unforeseen events may be a necessary remonstration to the logocentric assumptions of genetics. It has not been possible to set down, in the very beginning, a single definition of a gene, or static rules for gene transcription, translation or interaction. Perhaps it was the determination to define linear relations in biology which was monstrous. To return to Derrida again, 'Writing, like all artificial languages one would wish to fix and remove from the living history of the natural language, participates in the monstrosity. It is a deviation from nature'. He goes on, 'Spontaneous life must be protected' (Derrida, 1998, p. 38).

\section{Comprehensibility and Hospitality}


Yet, not all possibilities of fact cohere. Subtle mutations may not be picked up, not all mutants can be investigated, many mutations await phenotyping. So what is a potentially interesting mutant and which animals demonstrate these possibilities of fact? Whether altered through random mutations or knocking out known genes, the role of the gene is likely to be investigated by screening the animal's body to gather phenotypic information. The phenotype screen not only seeks to link genotype to phenotype, but also, through understanding the role of genes in mammalian development, links animal model and human disease. Here, the practices of functional genomics intersect, sometimes awkwardly, with the complex disciplinary practices and trajectories for the study of animal behaviour, veterinary pathology and clinical practice.

The task of bringing such disparate epistemic communities together, of making difficult decisions about the meaningful populations to screen, the number of screens on each animal, or the depth of screen in any disease area, is such that co-ordination of an international and integrated phenotpying programme lags well behind the development of the mutant models. These formal discussions are now progressing with some speed (Brown et al, 2005; Morgan et al 2010) ${ }^{4}$. However, even when agreements can be made about screening protocols, there are additional challenges in their implementation. There are questions about the distribution of expertise. There is now a relative lack of experience with mouse genetics, behaviour and pathology within the extended genetics community. The recent trajectories of training in molecular biology mean contemporary biologists may not encounter live mice in their academic training. The animal has not disappeared from the experimental practices of biology, but detailed knowledge of mice is increasingly limited to specialist animal caretakers rather than research scientists. Outside of the formal negotiations, and on a number of occasions, I am invited to join amused conversations about 'shaky pathology': the inability of expert researchers and peer reviewers to discern what is considered normal and what is pathological in mouse physiology.

Even within specialist facilities there are contingencies, as each institution may favour different protocols for testing animals. It is well known that the outcomes of phenotyping tests are influenced by animal husbandry, the order of experiments, and microbial and other environmental factors. It may be possible to control for these, but more than that, there are still unknown contingencies and operator effects which are more labile (Crabbe et al, 1999). Practices of testing within institutions and disciplinary areas are also slow to change. The

\footnotetext{
${ }^{4}$ For a recent review of responses to the KOMP survey on phenotyping see http://www.komp.org/phenotype/summary.php, last accessed $11^{\text {th }}$ May 2010.
} 
testing apparatus have evolutionary histories too, relating past and current research within disciplinary areas. As Hacking observes, 'there evolves a curious tailor-made fit between our ideas, our apparatus, and our observations. A coherence theory of truth? No, a coherence theory of thought, action, materials, and marks' (1992, p. 58). Many of the apparatus for testing differences in learning, memory, anxiety and social behaviours were developed through behavioural studies on rats. Despite a large and sometimes critical literature on phenotyping screens (Crawley, 2007; Justice, 2008), tests judged insensitive in screening populations are still routinely used in individual institutions (Brown and Balling, 2001). On such occasions, when Twenty-First Century functional genomics meets Twentieth Century neuroscience, it seems as if 'the time is out of joint' ${ }^{5}$. The spectre of the rat haunts the phenotyping of the mouse. And so there is another hesitation.

In an interview, this time in a coffee shop, a woman discusses her concerns about the value of the Morris Water Maze in testing the behaviours of genetically altered mice. She runs a phenotyping programme which characterizes mice for other researchers. She is frequently asked to use the Morris Water Maze to test mice. Yet, she suggests, this test may be meaningless, it may articulate research results with past data, but it is insensitive to these specific animals' bodies. The Morris Water Maze has been one of the preferred methods for screening animals for memory and spatial learning. The test is almost 30 years old (Morris, 1984), but its use is still increasing. It is popular for testing animal models for their relevance to research on Alzheimer's disease. In the test, the mouse swims in a shallow tray of water, until it locates an underwater platform, on which it can rest. In repeated experiments visual clues lead back to the platform, and the time taken to return is used as a measure of spatial learning and memory. The advantage of such tests is their simplicity and reproducibility. Data can easily be generated from new genetically altered animals and articulate with existing disciplinary data sets. The strange can be made comprehensible.

But something is lost in this subjection of the animal body to the demands of disciplinary contexts. The complex relations between gene expression and bodily capacities are obscured through the lack of fit between the experimental system in which the apparatus was developed and this new biological form. The Morris Water Maze was originally designed for rats, who love to swim. Mice, on the other hand, avoid water. She suggests the test may more accurately represent anxiety related behaviours in this species. The favoured laboratory strain of mice on which genetic alterations are inserted, the C57 black 6, loses eye-sight early due to

\footnotetext{
${ }^{5}$ This phrase, taken from Hamlet, forms the point of articulation for Derrida's (1994) text the Spectres of Marx.
} 
its inbred nature. The mice cannot see the markers. Maybe it is a test for residual sight. Or, there could be issues in gait which alter the animals' ability to swim. Perhaps it is a test of motor skills. Mice can communicate with ultrasonic vocalizations. The implications of this for behavioural tests are still being worked out, but perhaps what is tested is communication between animals. Of course, it may be all of these together. She is nearing retirement and feels her energies to fight these battles is limited. She pauses to prompt those requesting this test, but still carries them out on a regular basis.

This is another sense in which this research has monstrous potential. It has the potential to reveal and transform uneasy relations between the ideas, apparatus and observations used to link animal and human capacities. The Morris Water Maze has not become part of any largescale phenotyping screens I have seen, but the point is the same. The bodily capabilities of mice, their affective capacities, historical experiences, and social environments have to be comprehended in species relevant ways to address the complex articulations between genes, environment and phenotype. The specificities of these animals need to be taken seriously to answer pertinent and growing questions about the ability of this animal research to speak to the demands of translational medicine. This is the contemporary imperative - translational medicine - to move basic research to clinical and hospital settings. Hospital and hospitality share an etymology, from the Latin term hospes, referring to the guest, and pointing to acts of sheltering and welcoming. The need to be of value in providing care for the human body opens up questions about how we welcome these strange animal beings. It suggests a new kind of transaction between bodies than the equivalence drawn in the codes of genomics (see for example Davies, in press). But, even in language, these relations are complex and indeterminate. Trace the Indo-European root of the word back further to ghosti, signifying stranger, and the family of meanings is expanded to include ghosts as well as guests, hostility as well as hospitality. "The root notion, then, appears to be neither "host" nor "guest" but a complex of possible relations between strangers' (White, 1999, p. 15). This biology has to open up different ways of understanding the complex of possible relations between species, 'to welcome the monstrous arrivant, to welcome it, that is to accord hospitality to that which is absolutely foreign or strange' (Derrida, 1995, 387). The relative lack of expertise in whole animal biology, the shortage of behavioural ethology and veterinary pathology (Barthold et al, 2007), hinders this hospitality. As the number of mutant mice waiting to be phenotyped becomes a deluge (Abbott, 2004), these issues are increasingly, centrally, important.

\section{Monstrous ambiguities}


For those regulating animal research, securing the social contract on which animal experimentation in Europe is based, these experiments in functional genomics are also potentially excessive. The continuing increase in experimental animals works against widespread commitments to replace and reduce animals in biomedical research (Robinson et al 2003). Russell and Burch's 1959 book on The principles of humane experimental technique has been central to building widespread, if not universal, social and scientific approval for animal experimentation. Russell and Burch coined guiding principles for the 3Rs. These still underpin what is considered ethical animal experimentation, requiring experimenters to consider a priori the opportunities for refinement - minimising pain, suffering, distress or lasting harm to animals; replacement - considering alternative techniques for in silico methods, tissue cultures or lower organisms; and reduction - reducing the number of animals used by obtaining the same information from fewer animals or more information from the same number of animals. Although incorporated into different systems of governance, these guidelines for reducing the cost to animals have become the most widely accepted ethical framework for humane experimentation. These are then balanced against future benefits to humans. The UK Home Office, and Institutional Animal Care and Use Committees in the USA and elsewhere, require further evaluation through a cost-benefit analysis: this much cost to this many animals is balanced against these potential benefits to this area of human health.

Many of the individual welfare issues raised by large scale functional genomics are not new. They involve considerations for refining care for animals during experimental procedures and improving husbandry for animals with harmful mutations. In addition, for many of the animals involved, the procedures themselves may be minimally invasive, primarily involving breeding. Yet, in scaling such experimentation up from the individual gene to the animal genome, and shifting from the individual animal to the experimental system, new ethical issues arise. Judgements around reduction and replacement are more complex and the calculative basis of cost benefit analysis begins to break down. In some experiments, the induced mutations may be both harmless to the animal and useful to understanding human disease. For others, adverse mutations may not yield additional insights, or conversely, deleterious mutations may provide useful information. With ENU mutagenesis, there is also the chance of generating the same mutations again and again, so producing mutant animals which are of no supplementary value. There is no way of knowing in advance what the outcome of each experiment will be. Surprise is an integral component of all experimental design, but the parameters are more uncertain here. A clear cost-benefit calculation cannot be done for such open-ended techniques. The arrivant literally overspills 'the law'. 
This inability to calculate becomes evident during my attendance at a European animal welfare conference in 2009, within a discussion on genetic models. There are welfare scientists, biomedical researchers, animal groups and pharmaceutical companies present. The ethics of large-scale programmes in functional genomics become the particular focus of discussion. At one point, someone calls for a show of hands from those who would consider ENU mutagenesis to be unacceptable. A few hands go up, but almost everyone hesitates. There are some who will assert the unproblematic value of techniques like ENU mutagenesis. For them, it is the best way to develop new mutants which have novel potential for modelling diseases. The ethical imperative here is the need to do something to alleviate human suffering. It becomes a technological imperative. We can do this so we should do it, even if the outcomes are not clear. There are also those who assert, this is unethical, all animal experimentation should stop. Their position is a priori. They are not interested in refinements, reductions, only in replacement. These are both well established positions, and well known to each other, shaping the space for debate. But they are arguably no longer where the difficult and hesitant work of ethics is being done. Haraway is useful here. In When Species Meet she suggests, 'I refuse the "choice" of "inviolable animal rights" versus "human good is more important." Both of these proceed as if calculation solved the dilemma, and all I or we have to do is choose' (2008, p. 87). There may, instead, be value in 'staying with the trouble' (Haraway, 2010). Rather than seeking resolution through calculating cost and benefit, there is an ethical consequence to 'keeping the debate wide open by multiplying the signs of critical tension, of contradictions, or dilemmas, even aporias' (Derrida, 2002, p. 210).

I probe this hesitation in discussion with individuals later in the research. The inability to choose, the pause, is the start of some unexpected kinds of questioning. At the moment these are proceeding through personal narrative and anecdote as positions shift and new concerns, as well as new opportunities, emerge. I talk to someone from a laboratory animal supplier. She knows people who have left the industry, as they felt they could not kill another mouse. This is not the individual animal suffering which traditionally mobilises animal rights, but the personal affective toll taken by having to cull large numbers of apparently healthy animals. The practices of euthanasia, of providing a good death for animals at the end of the experiment, the process perhaps of 'killing well' (Haraway, 2008), becomes monstrous through sheer repetition. I talk to others working broadly within the animal care community. For them, there are opportunities for new interventions and collaborations around these animal numbers. They are working with funders and scientists to increase access to previously protected animals resources, to share already generated mouse models, to develop skills for cryopreserving animal strains, to co-ordinate the production of phenotype data and so reduce the number of live animals used across the research community. The ethical 
prompting of functional genomics is emerging around how to manage excess, whether experimental, corporeal or affective.

Following Haraway, it is possible to suggest these 'monsters' have promise, a promise to put diversity, difference and alterity at the centre of biology and to reshape biomedical practices around them. There is a return to biological complexity and a consideration of embodiment after the modernist logics of genomics. In the abstract I quoted Rabinow: 'if there ever was an example of brute life, the minimalist essence of things, it is genomics' (1999, p. 89). This period of genetic reductionism and determinism reached its limit. No one could say this now. The production of bodily diversity in mice is being used to say something different about the nature of embodied life. As the early grammars of genetics are decentred by its supplements, so other kinds of expertise and care are increasingly important. These mutant animals not only add biological understanding, they may also have the potential to question what it means to care for a body, and to be hospitable to bodily difference. In this, there are new potentialities, new associations, and new more diverse models of what it means to be an embodied human or nonhuman animal ${ }^{6}$. There are cautions as well, for there are those who may have no wish, or cannot find ways, to cede the authority or power they hold under older arrangements. Whilst I have enjoyed encounters with reflective individuals, the technical devices and commercial imperatives which articulate these animal bodies with past research, international efforts, and future treatments may be more resistant to change, and limit the things these bodies can say (see also Davies, 2010). And there is pathos too. Charged with finding ways of controlling mouse populations in the warehouses of post-war Britain, ethologist Peter Crowcroft set up a barn-sized experiment to explore the territorial and reproductive strategies through which these individual animals manage their own excessive potential. As Crowcroft watches the mice strive, succeed and fail, he notes 'the awakening of a sensibility I had formerly lacked; the capacity to feel compassion. There is something terribly familiar about the awful situation of a mouse in the world' (1966, p. 2).

\section{Relating post genomics}

The word monster is related to Monstrare, meaning to show forth or to signify (Shildrick, 2002). The same root gives us terms such as monitoring and demonstration, which have

\footnotetext{
${ }^{6}$ There are companies like Synaptologics in the Netherlands, offering direct links between the potential for phenotpying mouse diversity, the personal benefits of drug profiling and the assertion that each of us is strikingly different http://www.synaptologics.com/mousephenotyping.html, last accessed $11^{\text {th }}$ May 2010.
} 
become vital to scientific projects (Barry, 2001), but it also bring remonstrations too. The meanings of monstrosity thus cannot and should not be fixed. What is bought forth or signified by the emergence of the monstrous depends on relations between what is revealed and what is ruled out of bounds, and what comes next. The corporeality of the mouse is monstrous to the formerly logocentric languages of modernity and control. These animals potential for excess, their embodiment of biological generativity, intersects the imagination and organisation of sequencing endeavours, demonstrating the possibilities of thinking differently about relations in biology. They bring remonstrations too. The monstrous leads to questions about how to approach an ethics defined by excess and incalculability (Clark, 2005): about how to negotiate the limitations of existing ethical frameworks, about ways of defining responsible experimentation in conditions of uncertainty, about ways of being hospitable to bodily difference, about means of keeping debates open and considering multiple future possibilities. Post genomics is a challenge to language, to relations and to practice, for both the sciences and the social sciences too.

In conclusion, I want to return to the relations between corporeality, time, space and language at stake in the shifting cartographies of the monstrous. The mice themselves draw attention to the emerging spatio-temporal dynamics of this complexity. Genetics, when couched in deterministic and reductionist terms, tended to imply the possibility of predicting, calculating and intervening in the future, of controlling or altering biological destiny. This was the location of its most strident aspirations, and also its most trenchant critics (Jasanoff, 2006). In this determinist incarnation, ethical perspectives on genetics tended to oscillate between the technological imperative that something must be done, and the cautionary injunction that something should be proscribed, as if the ethico-political implications of biology merely involved varying velocities along a pre-designated technology trajectory. Yet, this was based on simplistic assumptions about genes that have been superseded. We now find ourselves somewhere different. The monstrosity of mice is a necessary remonstration to this reductionism. Just as modernist 'literature needs rats to riddle it with gaps' (Ellman, 2004, p. 71), so, by gnawing holes in the whole of nature (Milburn, 2003), the mice supplement genomics and supplant its perceptibility. As one Professor of Genetics, suggests,

'At the moment, we struggle with having three or four genes, when we make our drawings in PowerPoint. This will not be the way to tackle it in the next decade. [...] Some people have thought: why not do it, not with words, but maybe with tones. How can we receive the information? How can we visualise it? Of course I don't 
know. They're just weird ideas. But we have to work on that. For the future' (Professor of Genetics, Interview 2009).

These mice bore holes into the future, destabilizing the technological horizons imagined through genetic discourse at its most simplistic, opening up future possibilities and ways of thinking about the ethical. This monstrosity returns a future to this arena of biology; 'A future that would not be monstrous would not be a future; it would already be a predictable, calculable and programmable tomorrow' (Derrida, 1995, p. 386). There is a reaching towards something new, but it is uncertain and hesitant; the monstrous arrivant unsettles our conceptual and perceptual categories.

This alteration of temporal constraints changes spatial considerations too. The non-linearity of gene-environment interactions directs biomedical researchers to questions of spatiality. In contrast to the mapping topographies of genomics, the spatialities of post genomics are complex and folded. As Shostak observes, 'studies of gene-environment interaction create a challenging and productive tension - at the same time that bodies are being geneticized they also are emphatically emplaced' (Shostak 2003, p. 2327). The bodies of experimental animals and human patients are linked through their genetic relatedness, but they are also emphatically emplaced in their historically situated experiences. This renewed attention to localisation challenges both collaboration and translation. There are new issues raised by generating, distributing, phenotyping and archiving mutant mice across international facilities, as phenotypes may vary from place to place (Qiu, 2006; Valdar et al, 2006). The recognition that subtle differences in environment, husbandry and animal caretakers might affect phenotype is a confounding factor for these international collaborations organised around the delineation of gene function. The responses vary, from apparently infinite efforts to standardize everything everywhere, to recognition that environment, or space itself, has to be incorporated as a variable in post genomics. The 'envirotype' takes its place alongside the genotype and the phenotype (Beckers et al, 2009). This provides an additional hurdle to translational research (Sabroe et al, 2007), demanding explorations of equivalence, beyond genetic homologues, to facilitate the translation of biomedical insights between experimental animals and clinical spaces, including microbial environment, historical experience and individual biography. The emerging landscapes, and mindscapes, of post genomics have to deal with this immense complexity as the matrix of relationalities are both temporal and spatial.

The monstrous potential of post genomics is finally a challenge to the vocabularies of social science too. The critical social scientific commentaries of reductionist genetics suddenly 
seem somewhat beside the point. At a workshop in London $^{7}$, Kaushik Sunder Rajan, eloquently summarises this point: 'A simply oppositional critique that points to the limits of the ideologies and practices of the life sciences, it is clear, won't do anymore; but is what is left simply archiving, documenting, keeping pace with the rapidity, complexity and oftentimes magic of new developments in the life sciences? If so, whither critique?' There will not be one answer to these questions, but I have suggested, in this paper, there may be value in listening to pauses, as well as trying to keep pace. Each pause marks a comma, a potential opportunity, a point of undecidability, the advent of ethical or political reflection, whose implications can be amplified or dampened down as the 'reductionist returns' (Wynne 2005). These moments have import for understanding the future of the life sciences, as biological grammars and practices are remade, but they also exceed these experimental situations, with resonance for questions concerning our appetites for growth and innovation, our reconstruction of an ethics defined by excess, and our language for understanding lived relations and the will of both humans and animals. They require us to resist simple and singular definitions of the monstrous and to open up and engage with the unfolding relations between language, corporeality and space. As Derrida suggests, 'if things were simple, word would have gotten around' (Derrida, 1988, p. 119).

\section{Acknowledgements}

This paper arises from a research fellowship funded by the UK Economic and Social Research Council on 'Biogeography and Transgenic Life' [grant number RES-063-27-0093]. I am extraordinarily grateful to everyone working with mutant mice for their time, their reflections and their hospitality. My thanks to Deborah Dixon and Susan Ruddick for their invitation to participate in this special issue. Preliminary versions of this paper were presented to the Annual meeting of Association of American Geographers in Las Vegas $24^{\text {th }}$ March 2009 and to the Geography Department of the Open University $10^{\text {th }}$ February 2010. I am grateful for comments received there. I would like to thank Brian Balmer for formative comments, Erica Fudge for reflections on Francis Bacon, Jamie Lorimer and Beth Greenhough for ideas about monsters, Neal White for thoughts on chewing books, Helen Scalway for literary readings and Kaushik Sunder Rajan for conversations about Derrida and

\footnotetext{
${ }^{7}$ The Spaces of Transbiology Workshop was held on the 18th January 2010 at the Wellcome Trust, London, UK. This workshop formed part of the engagement activities for the ESRC fellowship Biogeography and Transgenic Life. For more information see http://www.geog.ucl.ac.uk/about-the-
} 
the challenge of post genomics. My thanks as well to the reviewers for their comments, both positive and perplexed, which helped clarify the scope of the final paper. The monstrous interpretation of these exchanges is of course my own responsibility.

department/people/academics/gail-davies/current-research-1/project-workshops-1, last accessed $11^{\text {th }}$ May 2010. See also Sunder Rajan (2006). 


\section{References}

Abbott, A., 2004. Geneticists prepare for deluge of mutant mice. Nature News 432, 541.

Anker, S., Nelkin, D., 2004. The Molecular Gaze: Art in the Genetic Age. Cold Spring Harbor Laboratory Press, Cold Spring Harbor, New York.

Austin, C., Battey, J., Bradley, A., Bucan, M., Capecchi, M., Collins, F., 2004. The knockout mouse project. Nature Genetics 36, 921-924.

Bacon, F., 1994 (original 1605). Advancement of Learning. Kessinger Publishing, Whitefish, Montana.

Baker, S., 2000. The Postmodern Animal. Reaktion Books, London.

Balling, R., Brown, S., Hrabé de Angelis, M., Justice, M., Nadeau, J., Peters, J., 2000. Great times for mouse genetics: getting ready for large-scale ENU-mutagenesis.

Mammalian Genome 11 (7), 471.

Balmer, B., 1996. Managing mapping in the Human Genome Project. Social Studies of Science 26 (3), 531-573.

Barry, A., 2001. Political Machines: Governing a Technological Society. Athlone Press, London.

Barthold, S., Borowsky, A., Brayton, C., Bronson, R., Cardiff, R., Griffey, S., Ince, T., Yu Nikitin, A., Sundberg, J., Valli, T., Ward, J., 2007. From whence will they come? A perspective on the acute shortage of pathologists in biomedical research. Journal of Veterinary Diagnostic Investigation 19 (4), 455-456.

Beck, J., Lloyd, S., Hafezparast, M., Lennon-Pierce, M., Eppig, J., Festing, M., Fisher, E., 2000. Genealogies of mouse inbred strains. Nature Genetics 24, 23-25.

Beckers, J., Wurst, W., Hrabé de Angelis, M. 2009. Towards better mouse models: enhanced genotypes, systemic phenotyping and envirotype modelling. Nature Reviews Genetics, 10, 371-380.

Berry, R., 2008. Town Mouse, Country Mouse: adaptation and adaptability in Mus domesticus (M. musculus domesticus). Mammal Review 11 (3), 91-136.

Botting, F., 2003. Metaphors and Monsters. Journal for Cultural Research 7 (4), 339-365.

Boursot, P., Auffray, J., Britton-Davidian, J., Bonhomme, F., 1993. The evolution of house mice. Annual Review of Ecology and Systematics 24, 119-152.

Brown, S., Chambon, P., Hrabé de Angelis, M., 2005. EMPReSS: standardized phenotype screens for functional annotation of the mouse genome. Nature Genetics, 37, 1155.

Brown, S., Balling, R., 2001. Systematic approaches to mouse mutagenesis. Current Opinion in Genetics \& Development 11 (3), 268-273.

Burt, J., 2006. Rat. Reaktion Books, London. 
Canguilhem, G., Jaeger, T., 1962. Monstrosity and the Monstrous. Diogenes, 10, 27-42.

Chouard, T., 2010. Evolution: Revenge of the hopeful monster. Nature 463, 864-867.

Clark, N., 2005. Facing Disaster: Dynamic Instability and Exorbitant Ethics. Paper presented at Complexity, Science and Society Conference, Lancaster. Available at http://www.lancs.ac.uk/ias/researchgroups/complexity/liverpoolconference.htm. Last accessed $10^{\text {th }}$ May 2010.

Clayton, B., 2005. The Human Genome Project: An increasingly elusive 'human nature'. Semiotica 155 (1), 249-258.

Coetzee, J.M., 2003. Elizabeth Costello. Secker and Warburg, London.

Collins, F., Rossant, J., Wurst, W., 2007. A mouse for all reasons - International Knockout Consortium. Cell 128, 9-13.

Cook-Deegan, R., 1994. The Gene Wars. W.W Norton, NewYork.

Crabbe, J.C., Wahlsten, D., Dudek, B.C., 1999. Genetics of mouse behaviour: interactions with laboratory environment. Science 284, $1670-1672$.

Crawley, J., 2007. What's wrong with my mouse? Behavioral phenotyping of transgenic and knockout mice. Wiley-Interscience, Hoboken, NJ.

Crowcroft, P., 1966. Mice all over. Foulis, London.

Darwin, C., 1996 (original 1859). The Origin of Species. Oxford University Press, Oxford.

Daston, L., Park, K., 1998. Wonders and the Order of Nature 1150-1750. Zone Books, New York.

Davies, G., 2003. A geography of monsters? Geoforum 34 (4), 409-412.

Davies, G., 2010. Captivating behaviour: mouse models, experimental genetics and reductionist returns in the neurosciences. In: Parry, S., Dupré, J. (Eds.) Nature after the Genome. Wiley-Blackwell, Oxford, pp. 53-72.

Davies, G., in press. What is a humanized mouse? Remaking the species and spaces of translational medicine. Body \& Society.

Davisson, M., 2006. FIMRe: Federation of International Mouse Resources: global networking of resource centers. Mammalian Genome 17 (5), 363-364.

Deleuze, G., 2005. Francis Bacon. Continuum Books, London.

Derrida J., 1994. Spectres of Marx. Routledge, London.

Derrida, J., 1988. Limited Inc. Northwestern University Press, Evanston, IL.

Derrida, J., 1995. Passages - from traumatism to promise. In: Weber, E. (Ed.) Points ... Interviews 1974-1994. Stanford University Press, Stanford, pp.372-395.

Derrida, J., 1998. Of Grammatology. John Hopkins University Press, Baltimore.

Derrida, J., 2002. The aforementioned so-called human genome. In: Rottenberg, E. (Ed.) Negotiations. Stanford University Press, Stanford, pp 199-215. 
Dixon, D., 2008. The blade and the claw: science, art and the creation of the lab-borne monster. Social and Cultural Geography 9 (6), 671-692.

Ellman, M., 2004. Writing like a rat. Critical Quarterly 46 (4), 59-76.

Evans, E.P., 1906. The criminal prosecution and capital punishment of animals. William Heinemann, London.

Foucault, M., 2003. Abnormal: Lectures at the Collège de France 1974-1975. Picador, New York.

Franklin, S., 2006. The cyborg embryo: our path to transbiology. Theory, culture and society 23, 167-187.

Freeman, B., 1987. 'Frankenstein' with Kant: a theory of monstrosity, or the monstrosity of theory. SubStance 16 (1), 21-31.

Gondo, Y., 2008. Trends in large-scale mouse mutagenesis: from genetics to functional genomics. Nature Reviews Genetics 9, 803-810.

Grimm, G., 2006. A mouse for every gene. Science 312 (5782), 1862-1866.

Hacking, I., 1992. The self-vindication of the laboratory sciences. In: Pickering, A. (Ed.) Science as Practice and Culture. Chicago University Press, Chicago, pp. 29-64. Haraway, D., 1992. The promises of monsters: a regenerative politics for inappropriate/d others. In Grossberg, L., Nelson, C., Treichler, P. (Eds.) Cultural Studies. Routledge, London, pp. 63-124.

Haraway, D., 1997. Modest_Witness@Second_Millenium.FemaleMan@_Meets_Oncomouse ${ }^{\mathrm{TM}}$ : Feminism and Technoscience. Routledge, London.

Haraway, D., 2008. When Species Meet. University of Minnesota Press, Minneapolis.

Haraway, D., 2010. When Species Meet: staying with the trouble. Environment and Planning D: Society and Space 28 (1), 53-55.

Hrabé de Angelis, M., Flaswinkel, H., Fuchs, H., Rathkolb, B., Soewarto, D., Marschall, S., 2000. Genome-wide, large-scale production of mutant mice by ENU mutagenesis. Nature Genetics 25, 444-447.

Jasanoff, J., 2006. Clones and critics in the age of biocapital. Biosocieties 1, 266-269.

Justice, M., 2008. Removing the cloak of invisibility: phenotyping the mouse. Disease Models \& Mechanisms 1, 109-112.

Kay, L., 2000. Who wrote the book of life? A history of the genetic code. Stanford University Press, Stanford.

Keller, E., 2002. The Century of the Gene. Harvard University Press, Cambridge, MA. Leonelli, S., 2008. Bio-ontologies as tools for integration in biology. Biological Theory 3 (1), 7-11. 
Lezaun, J., 2010. The risk regulation of 'frontier research': the case of gene therapy. In:

Hutter, B. (Ed.) Anticipating Risks in the 21st Century. Cambridge University Press, Cambridge.

Milburn, C., 2003. Monsters in Eden: Darwin and Derrida. MLN 118, 603-621.

Morgan, H., Beck, T., Blake, A., Gates, H., Adams, N., Debouzy, G., Leblanc, S., Lengger, C., Maier, H., Melvin, D., Meziane, H., Richardson, D., Wells, S., White, J., Wood, J., The EUMODIC Consortium, Hrabé de Angelis, M. Brown, S., Hancock, J., Mallon, A., 2010. EuroPhenome: a repository for high-throughput mouse phenotyping data Nucleic Acids Research 38, Database issue D577-D585.

Morris, R., 1984. Developments of a water-maze procedure for studying spatial learning in the rat. Journal of Neuroscience Methods 11 (1), 47-60.

Neocleous, M., 2005. The Monstrous and the Dead: Burke, Marx, Fascism. University of Wales Press, Cardiff.

Pickstone, J., 2001. Ways of knowing: A new history of science, technology, and medicine. University of Chicago Press, Chicago.

Qiu, J., 2006. Animal research: Mighty mouse. Nature 444, 814-816.

Rabinow, P., 1996. Essays on the Anthropology of Reason. Princeton University Press, Princeton.

Rabinow, P., 1999. French DNA: Trouble in Purgatory. University of Chicago Press, Chicago.

Rader, K., 2004. Making Mice: Standardizing Animals for American Biomedical Research, 1900-1955. Princeton University Press, Princeton.

Ritvo, H., 1998. The platypus and the mermaid, and other figments of the classifying imagination. Harvard University Press, Cambridge, MA.

Robins, R., 2008. Inventing Oncomice: making natural animal, research tool and invention cohere. Genomics, Society and Policy 4 (2), 21-35.

Robinson, V., Morton D., Anderson, D., Carver, J., Francis, R., Hubrecht, R., Jenkins, E., Mathers, K., 2003. Refinement and reduction in production of genetically modified mice. Sixth report of the BVAAWF/FRAME/RSPCA/UFAW Joint Working Group on Refinement. Laboratory Animals 37, 1-51.

Rosenthal, N, Brown, S., 2007. The mouse ascending: perspectives for human-disease models. Nature Cell Biology 9, 993-999.

Ruddick, S., 2004. Domesticating Monsters: cartographies of difference and the emancipatory city. In: Lees, L. (Ed.) The emancipatory city? Paradoxes and Possibilities. Sage Publications Ltd, London, 23-39.

Russell, W., Burch, R., 1959. The Principles of Humane Experimental Technique. Methuen, London. 
Sabroe, I., Dockrell, D., Vogel, S., Renshaw, S., Whyte, M., Dower, S., 2007. Identifying and hurdling obstacles to translational research. Nature Reviews Immunology 7, 7782.

Schlick, T., 2005. The critical collaboration between art and science: an experiment on a bird in the air Pump and the ramifications of genomics for society. Leonardo 38 (4), 323329.

Shildrick, M., 2002. Embodying the Monster: Encounters with the vulnerable self. Sage Publications Ltd, London.

Shostak, S., 2003. Locating gene-environment interaction: at the intersections of genetics and public health. Social Science \& Medicine 56 (11), 2327-2342.

Sunder Rajan, K., 2006. Biocapital: The Constitution of Postgenomic Life. Duke University Press, Durham, NC.

Turney, J., 1998. Frankenstein's Footsteps: Science, Genetics and Popular culture. Yale University Press, New Haven.

Valdar, W., Solberg, L., Gauguier, D., Cookson, W., Rawlins, N., Mott, R., Flint, J., 2006.

Genetic and environmental effects on complex traits in mice. Genetics 174, 959-984.

White, S., 1999. Dreamwork as etymology. Dreaming 9 (1) 11-21.

Wynne., B., 2005. Reflexing complexity: post-genomic knowledge and reductionist returns in public science. Theory, Culture \& Society $22,67-94$. 